ISSN 0258-7122

Bangladesh J. Agril. Res. 37(1): 49-54, March 2012

\title{
ECONOMICS OF RAINFED SERICULTURE-A STUDY IN THE DISTRICT OF UDAIPUR IN RAJASTHAN, INDIA
}

\author{
RUCHIRA SHUKLA ${ }^{1}$
}

\begin{abstract}
Sericulture is a labour intensive agro-based rural industry, which provides periodical income throughout the year. In view of this, it is very much imperative to know the sericulture economics in order to motivate new farmers to take up sericulture and increase their income. Therefore, a study was conducted with the help of personal interview of 70 rainfed sericulture farmers in Udaipur district of Rajasthan, India. The study concluded that in garden establishment, highest share of cost was associated with human labour (INR 14,400.00) followed by that for FYM (INR 2418.75). Similarly human labour (51.93\%) accounted for highest element of cost in leaf production activities too owing to high labour wages and shortage of manpower. Labour (25.33\%) was second major cost component next to mulberry leaf (38.64\%) in silk cocoon production. The average yield of silk cocoon obtained was $1289.04 \mathrm{~kg} / \mathrm{ha}$ per year. The net return obtained was INR 52039.32 and benefit cost ratio was 1.49.
\end{abstract}

Keywords: Sericulture, economics, mulberry, cocoon.

\section{Introduction}

Sericulture plays a vital role in rural development, as it integrates well with the farming systems and has the potential to generate attractive income throughout the year. It needs low capital and provides year round employment (Hanumappa and Erappa, 1985). India stands second in raw silk production after China. Mulberry sericulture is practiced in India in 1, 91,893 ha with annual production of 16525 MT. India exported silk goods worth Mn. US\$ 737.76 in year 2006-07 (Anonymous, 2007). With the advent of new bivoltine sericulture technologies, the sericulture productivity is changing fast with an upward trend. At the same time, there is change in nature, quantity and cost of input required. In view of this, it is very much imperative to know the sericulture economics and it is highly essential to motivate the new farmers to take up sericulture and increase their income. Some studies were earlier attempted to find out the economic prospects of sericulture at the farmer's level in various parts of India (Anonymous, 1989, Ravindran et al., 1993, Lakshmanan et al., 1996). Therefore, the present study was aimed at following objectives:

i) to find out the cost of establishment of mulberry garden in Udaipur district.

\footnotetext{
${ }^{1}$ Associate Professor, Institute of Agribusiness Management, Navsari Agricultural University, Navsari-396450, Gujarat, India.
} 
ii) to find out the cost associated with mulberry leaf production in Udaipur district;

iii) to work out cost and returns from a unit area under mulberry cultivation and silkworm rearing.

\section{Research Methodology}

The present research study has been conducted in Udaipur district of Rajasthan during 2007-08. Two tehsils, namely Mavli and Jhadol of Udaipur district were selected purposively because of having maximum number of sericulture adopters in the district. The list of villages along with the name of adopters including year of adoption of sericulture of selected tehsils was obtained from the voluntary institute Rajasthan Vidyapeeth working especially on sericulture in these two tehsils. From the list of sericulture adopters of the selected village, 70 adopters (35 from each tehsil) who were engaged in sericulture since last 2-3 years, were selected randomly for the purpose of personal interview. A pre-tested schedule was administered to collect information on cost incurred for different inputs and return including value of by-products. Simple cost accounting method was employed to work out cost and return profile of mulberry leaf production and silkworm rearing per hectare per year. The total cost consists of fixed and variable cost components. The total cost of garden establishment was divided and accounted for 15 years to arrive at the share of fixed costs per annum using net present value method while calculating cost of mulberry leaf production. Gross returns were calculated using returns from cocoons and byproducts.

\section{Results and Discussion}

The cost of establishment of mulberry garden in Udaipur district is presented in Table 1 . The cost items considered for garden establishment were human labour, animal power, machine power, farm yard manure (FYM), planting material, irrigation, and interest on total investment. The highest share of the cost associated with garden establishment was incurred for human labour (INR 14,400.00) followed by that for FYM (INR 2418.75).

The data presented in Table 2 revealed that cost matrix on production of mulberry leaf (per ha/year). The total cost consists of fixed and variable cost components. The total cost of garden establishment was divided and accounted for 15 years to arrive at the share of fixed cost per annum. The total variable cost is of different inputs applied viz., human labour, animal labour, FYM, chemical fertilizers, irrigation, and interest on working capital. It is interesting to record that about 66.97 percent (INR 30600.00) of total cost was incurred for human labour in leaf production activities. The higher labour cost incurred was due to higher wages of labour and shortage of manpower. The cost incurred in chemical fertilizers was 7.72 percent (INR 3758.06) of total cost, whereas in FYM, it was 
6.65 percent (INR 3240.00) of the total cost. The cost of labour, chemical fertilizers, and FYM put together accounted for about 81.34 percent of the total production cost. Jayram et al. (1996) pointed out that the high cost on inputs is due to lack of awareness about inputs and reluctance of farmers in accepting the improved practices generated by the research institutes.

Table 1. Cost (INR per ha) of establishment of mulberry garden in Udaipur district $(\mathrm{N}=\mathbf{7 0})$.

\begin{tabular}{|c|c|c|c|c|c|}
\hline $\begin{array}{l}\text { S1. } \\
\text { No. }\end{array}$ & Variables & Unit & $\begin{array}{l}\text { Physical } \\
\text { quantity }\end{array}$ & Cost & \% Share \\
\hline 1. & Human labour & Man days & 180 & 14400.00 & 53.64 \\
\hline 2. & Animal power & Animal days & 4.27 & 1115.75 & 4.15 \\
\hline 3. & Machine power & Hours & 6.75 & 1738.12 & 6.47 \\
\hline 4. & Farm yard manure & Tons & 18.0 & 2418.75 & 9.01 \\
\hline 5. & Chemical fertilizers & $\mathrm{kg}$ & 227.7 & 1650.82 & 6.14 \\
\hline 6. & Irrigation & INR & -- & 2418.75 & 9.01 \\
\hline 7. & Cuttings and saplings & INR & -- & 877.5 & 3.26 \\
\hline 8. & Land tax & INR & -- & 236.25 & 0.88 \\
\hline \multirow[t]{2}{*}{9.} & $\begin{array}{l}\text { Interest on working } \\
\text { capital (@ 8\% p.a. }\end{array}$ & INR & -- & 1988.47 & 7.40 \\
\hline & Total & -- & -- & 26844.41 & 100.00 \\
\hline
\end{tabular}

Table 2. Cost (INR per ha) of mulberry leaf production in Udaipur district $(\mathrm{N}=\mathbf{7 0})$.

\begin{tabular}{|c|c|c|c|c|}
\hline $\begin{array}{l}\text { S1. } \\
\text { No. }\end{array}$ & Variables & $\begin{array}{l}\text { Physical } \\
\text { quantity }\end{array}$ & Cost & $\begin{array}{c}\% \text { Share in } \\
\text { total cost }\end{array}$ \\
\hline \multirow[t]{9}{*}{1.} & \multicolumn{4}{|l|}{ Operational cost } \\
\hline & 1.1 Human labour (Man days) & 382.5 & 30600.00 & 66.97 \\
\hline & 1.2 Animal labour (animal days) & 4.52 & 1174.5 & 2.41 \\
\hline & 1.3 Farm yard manure (tons) & 18.00 & 3240.00 & 6.65 \\
\hline & 1.4 Chemical fertilizers (kg) & 518.35 & 3758.06 & 7.72 \\
\hline & 1.5 Irrigation (INR) & -- & 3292.94 & 6.76 \\
\hline & 1.6 Land tax (INR) & -- & 236.25 & 0.48 \\
\hline & $\begin{array}{l}1.7 \text { Interest on working capital @ } \\
\text { 8\% p.a. }\end{array}$ & -- & 3384.14 & 6.95 \\
\hline & Operational cost & -- & 45685.89 & 93.89 \\
\hline 2. & $\begin{array}{l}\text { Fixed cost (share of establishment of } \\
\text { mulberry garden per ha) }\end{array}$ & -- & 2969.57 & 6.10 \\
\hline 3. & Total $(1+2)$ & -- & 48655.46 & 100.00 \\
\hline
\end{tabular}


The cost of silk cocoon production per ha/year in Udaipur district is shown in Table 3. Labour was the major cost component next to mulberry leaf production, which amounts to INR 26,835.34. The cost of silkworm seed was INR 7,023.46. Depreciation cost on rearing house and rearing equipment, which was accounted as fixed cost in silkworm rearing was INR 16,030.26. The total cost of cocoon production per ha/year worked out to INR 1,05,920.64. Neelakantsastry (1982), Marihonnaiah (1986) and Kulkarni (1993), identified that human labour and dfls had positive and significant association with cocoon production.

Table 3. Cost and return (INR/ha/year) structure from cocoon production $(\mathrm{N}=70)$.

\begin{tabular}{|c|c|c|c|}
\hline S1. No. & Variables & Cost & $\begin{array}{l}\text { Share of total } \\
\text { cost }(\%)\end{array}$ \\
\hline \multirow[t]{5}{*}{ I } & Fixed cost & & \\
\hline & 1. Depreciation on rearing house and & 16030.26 & 15.13 \\
\hline & equipment & & 1.31 \\
\hline & 2. Interest on fixed capital @ 8 p.a. & 1388.97 & \\
\hline & Total fixed cost (I) & 17419.23 & 16.44 \\
\hline \multirow[t]{8}{*}{ II } & Operational cost & & \\
\hline & 1. Human labour & 26835.34 & 25.33 \\
\hline & $\begin{array}{l}\text { 2. Disease free larvae including chawkie } \\
\text { change }\end{array}$ & 7023.46 & 6.63 \\
\hline & 3. Materials & 8607.46 & 8.12 \\
\hline & 4. Marketing & 1575.33 & 1.49 \\
\hline & 5. Interest on working capital @ 8\% p.a. & 3523.32 & 3.32 \\
\hline & 6. Mulberry leaf & 40936.5 & 38.64 \\
\hline & Total Operational Cost (II) & 88501.41 & 83.55 \\
\hline \multirow[t]{4}{*}{ III } & Return & & \\
\hline & 1. Gross return & 157959.96 & -- \\
\hline & 2. Total cost $(1+11)$ & 105920.64 & -- \\
\hline & 3. Net return & 52039.32 & -- \\
\hline
\end{tabular}

Table 4 presents the details of earning of the sample farmers of two tehsils of Udaipur district from cocoon production. The respondents brushed silkworm seed ( $2475 \mathrm{dfls} / \mathrm{ha} /$ year). The production was lower due to the drought prevailing from 2002 onwards, water source, such as open well and tube wells are becoming dry and hence the brushing capacity has fall down. Due to that the farmers are either forced to cut short the brushing quantity or to stop rearing during summer months. The average yield obtained by farmers was $1289.04 \mathrm{~kg} / \mathrm{ha} / \mathrm{year}$. The 
returns from sale of cocoon were INR 142117.47. The income generated from by-products was INR 15842.49. The net return per ha/year was INR 52039.32. The benefit cost ratio was worked out to be 1.49 . Table 4 summarizes the major economic events.

Table 4. Summary of major economic events $(\mathrm{N}=70)$.

\begin{tabular}{lllll}
\hline $\begin{array}{r}\text { S1. } \\
\text { No. }\end{array}$ & \multicolumn{1}{|c|}{ Particulars } & Units & \multicolumn{1}{c}{ Value } \\
\hline 1. & Average area under mulberry & Hectare & 0.57 \\
\hline 2. & Leaf yield (ha/year) & $\mathrm{kg}$ & 34047.45 \\
\hline 3. & Cost of leaf (ha/year) & INR & 48655.46 \\
\hline 4. & Cost of leaf/kg & INR & 1.11 \\
\hline 5. & Average number of dfls brushed (peryear) & No. & 2475 \\
\hline 6. & Cocoon yield (ha/year) & kg & 1289.04 \\
\hline 7. & Average no. of crop (/year) & No. & 4 \\
\hline 8. & Cocoon cost (ha/year) & INR & 105920.64 \\
\hline 9. & Gross income (ha/year) & -- & -- \\
\hline & --From cocoon (A) & INR & 142117.47 \\
& --From the by-products & INR & 15842.49 \\
& Total (A+B) & INR & 157959.96 \\
\hline 10. & Average cocoon price (Rate/kg) & INR & 110.25 \\
\hline 11. & Benefit Cost ratio & -- & 1.49 \\
\hline
\end{tabular}

\section{Conclusion}

The present study draws the following implications for the perspective development of sericulture in long run in the study regions. The study indicates that sericulture has a good potential to generate attractive income for the farmers. It is more labour intensive and has low capital requirement and serve a good option for small farmers to gain meaningful employment and income throughout the year. In order to reduce the cost of production, the farmers should be motivated and demonstrated with the adoption of new bivoltine sericulture techniques. The sericulturists should be educated about the optimum use of inputs, such as fertilizers, pesticides and motivated to use INM/IPM/IDM approaches besides water conservation techniques. To encourage bivoltine sericulture, scope for minimum support price (MSP) for commercial bivoltine cocoon should be looked into. 


\section{References}

Anonymous. 1989. An economic survey of sericulture in Tamilnadu. Deptt. Of Agricultural Economics, Tamilnadu Agricultural University, Coimbatore, Tamilnadu, India.

Anonymous. 2007. Annual Report. DGCIS, Ministry of commerce, Govt. of India. Hanumappa, H.G. and Erappa,S. 1985. Economic issues in sericulture: study of Karnataka. Economic and Political Weekly 20(31):3122-3224.

Jayaram, H., R. Ganapatathi Rao, S. Lakshmanan and B. Mallikarjuna. 1996. Role of input delivery system in sericulture-An empirical study. Central Silk Board, Bangalore.

Kulkarni, V.S. 1993. Yield gaps analysis of bivoltine (NB4D2) cocoon production in Mandya district. CSRTI, Mysore.

Lakshmanan, S., B. Mallikarjuna, H. Jayaram, R. Ganapathy Rao, M. R. Subramanian, R.G. Geeta Devi and R. K. Dutta. 1996. Economic issues of production of mulberry sericulture in Tamilnadu-Micro-economics study. Indian J. Seric. 35(2): 128-131.

Marihonnaiah, Y. 1986. Studies resource productivity in cocoon production in tumkur district of Karnataka. M. Sc. (Agril.) Thesis, University of Agricultural Sciences, Bangalore, India.

Neelakantasastry, T.V. 1982. Cost structure of sericulture industry in Chittor district of Andhra Pradesh. M. Sc. (Agri.) Thesis. Andhra Pradesh Agricultural university, Hyderabad, India.

Ravindran, N., S. Anita, B. Parthipan and S. Elangovan. 1993. Sericulture: A profitable farm venture. Agricultural Situation in India 18 (3): 23-26. 